\title{
Correlation of the Increase in the Transportation Infrastructure Development Budget with a production surplus
}

\author{
Theresia Widi Asih Cahyanti ${ }^{1,3^{*}}$, Achmad Munawar ${ }^{2}$, and Bambang Riyanto ${ }^{1}$ \\ ${ }^{1}$ Department of Civil Engineering, Diponegoro University, Semarang 50275, Indonesia \\ ${ }^{2}$ Department of Civil and Environmental Engineering, Gadjah Mada University, Yogyakarta 55281, Indonesia \\ ${ }^{3}$ Department of Civil Engineering, Musamus University, Merauke 99600, Indonesia
}

\begin{abstract}
In this study, identify the function of the road construction budget for transportation infrastructure can trigger an increase the output surplus of production was done. The increase in the road development budget is calculated using the growth factor method of the road construction budget combined with the length of the road. The production surplus is calculated based on the productivity of the commodity compared to the commodity needs of the population in the regency. The research method used excel software. The object under study is the surplus of commodity production taken and processed based on data from the Central Bureau of Statistics for last 10 years. Meanwhile, the road construction budget data were obtained related agencies for the last 5 years. The expected result in this research is to obtain a correlation between the road construction budget and the production surplus.
\end{abstract}

Keywords: Budget, Commodities, Production surplus, Transportation infrastructure

\section{Introduction}

In the last few years, development in Indonesia's territory has been prioritized in rural areas by strengthening economic independence to increase people's productivity. Merauke Regency is one of the regencies located on the edge of Indonesia's territory bordering other countries. So that Merauke Regency becomes one of the development goals oriented towards people's productivity in improving the economy. Merauke Regency is one of the largest districts in Papua province even in the territory of Indonesia with an area of 46,791.63 square kilometer [1]. Meanwhile, the population living in the area is only 225,714 people, and if seen from the population density, it is only 4.82 people per square kilometer. With a large area, there is a land potential of $1,236,976.83$ hectares based on the spatial plan for the Merauke Regency area. Currently, the land that has been used for both agriculture and plantations is $138,078.6$ hectares or $11.14 \%$ of the potential land with an average land growth rate of $15.80 \%$ per year [1]. With the increasing land used for agricultural and plantation commodities, the production of these commodities will also increase, especially supported by the large potential of the existing land. However, the potential for these commodities has not been fully utilized because it is caused by various factors. One of the factors that cause commodity potential is still limited is the limited road transportation infrastructure in Merauke Regency. This can be seen from the length of existing roads in the Merauke Regency. The current length of roads in Merauke Regency is only 1,820.21 km and there has been no additional road length since 2014 [1].

The transportation sector has always been associated with the economic sector, where transportation is very supportive of the economic sector. According to Anas et al. [2] that there is a role of investment in transportation infrastructure will affect saving the cost of transportation of goods. So, this study aims to analyze whether an increase in the budget for road transportation infrastructure development can increase a significant surplus of agricultural commodity production in Merauke Regency.

\section{Literature Review}

Transportation activities provide a positive correlation to economic activities and development in the community. Transportation is a tool that is used to obtain economic benefits in various fields. The important role of transportation services, among others, is to smoothen the flow of goods and human mobility, to optimize economic resources. By maximizing the implementation of economic resources, production activities can run effectively and efficiently so that there are large job opportunities and an increase in community income, thereby reducing the gap between residents in various regions [3]. Infrastructure plays an important role in improving the welfare of human life and also

\footnotetext{
* Corresponding author : cahyanti@unmus.ac.id
} 
encourages increased investment. Likewise, the transportation infrastructure. With the existence of transportation infrastructure, it will open up wide and fast physical access to economic activities from areas of surplus production to centers of economic activity [4]. According to Anas, et al [2] transportation costs will be a cost component in calculating the production costs of a commodity. The level of transportation costs can affect the growth in production rates in an area. If the cost of transportation is low, there will be high growth in production figures and will open up wider marketing. Conversely, if the production costs are high, it will affect the production costs which will affect the selling price of production. The increase in road construction increased agricultural development. This can be seen in the increasing use of agricultural land. So it can be concluded that road infrastructure development influences agricultural development [5]. In another study, Tamene and Megento [6] said that an increase in rural road infrastructure and access to transportation services would increase the purchasing power of farmers for chemical fertilizers and superior seeds. So that it will increase farmers' income and occur with economic growth. This is in line with the opinion of Prasetyo and Firdaus [7] and Maryaningsih [8] who said in their research that economic growth is strongly influenced by infrastructures such as the availability of electricity, paved roads, and clean water so that it will achieve high and sustainable growth.

\section{Research Method}

This research was conducted in Merauke Regency using data from the Central Bureau of Statistics for the last 10 years (2009-2019) in the form of population, area of agricultural and plantation land, the amount of production of an agricultural and plantation commodity. This data is used to find a production surplus that occurs based on commodity productivity compared to the needs for commodities used by residents in the Merauke regency. For road development budget data and road conditions using data from the PJN Work Unit for national roads, the provincial public works office for provincial roads, and from the regency public works office for regency roads taken during the last 5 years (2014-2019). The data will be calculated using a growth factor combined with the length of roads in the Merauke regency. The method used in this study used excel software to find a correlation between the increase in the road infrastructure development budget and the producer surplus that occurred in the Merauke regency.

\section{Results and Discussion}

The steps in this research are as follows:

1. Based on the land area in the last 10 years, the predicted growth in the average land area for the next 20 years can be calculated. The land area in Merauke Regency has increased from year to year and has increased quite significantly in 2018, namely $34.13 \%$. as shown in Figure 1 . The area of land that has been used is $138,078.6$ hectares from the potential land area of $1,236,976.83$ hectares.

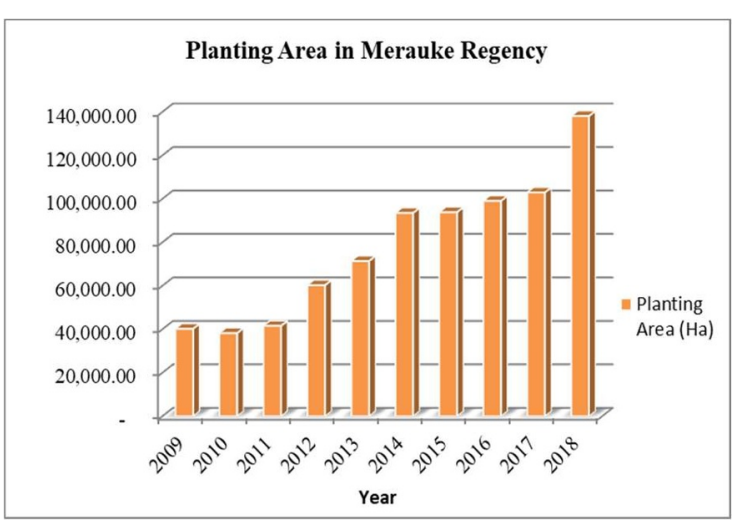

Fig. 1. Planting Area.

2. With data on the yield of a commodity, it can be calculated that the yield growth of production commodities is adjusted to the land area obtained from the predicted yield for the next 20 years. Based on production data from the Central Bureau of Statistics of Merauke Regency, on average there is an increase in production as the land area increases, namely $17.05 \%$. Commodity production increased greatly in 2018 , amounting to $425,460.83$ tons or an increase of $51.81 \%$. Production yields have fluctuated from year to year, this can be caused by various factors, but the average production output has increased as shown in Figure 2.

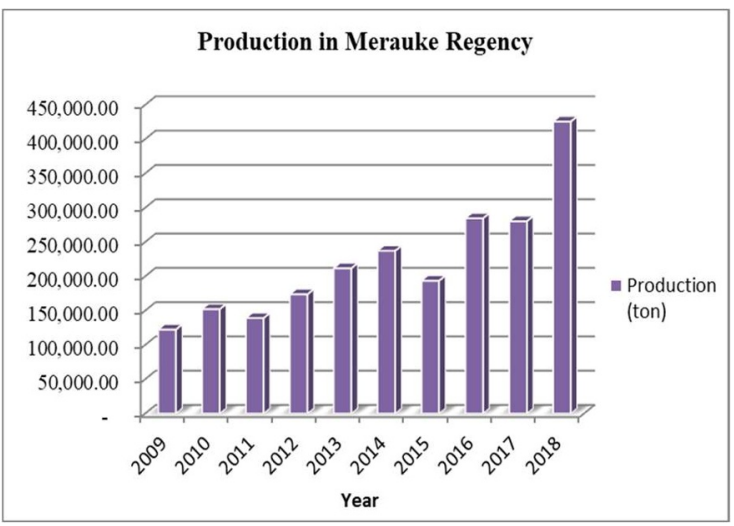

Fig. 2. Production commodity

3. The population for 10 years taken from the Central Bureau of Statistics of Merauke Regency is shown in Figure 3 and the growth is also calculated for the next 20 years. Population growth in Merauke Regency has consistently increased by an average of $2 \%$ per year as shown in Figure 3 . The total population in 2018 was 225,714 people with a population density of 4.82 people per square kilometer. With a constant increase in population, while a significant increase in production, it is estimated that population consumption needs for agricultural production will be sufficient, and there will even be a production surplus. 


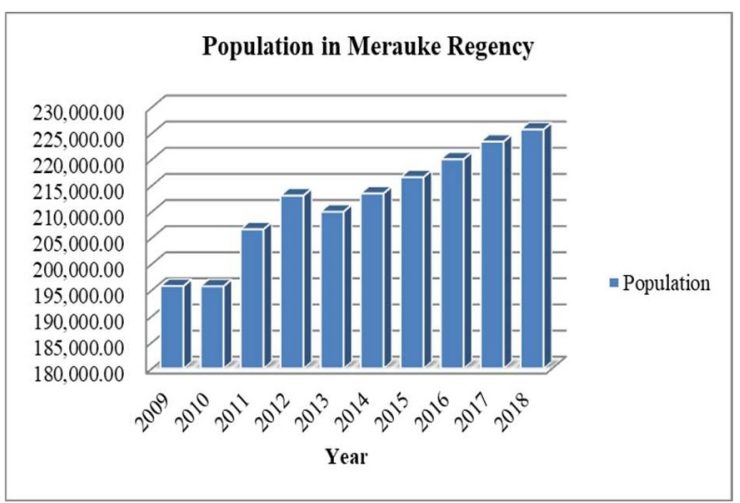

Fig. 3. Population

4. The growth of the road development budget data is calculated which is taken from the road construction budget data from the previous years.

5. Looking for the relationship between the producer surplus and the road construction budget, namely the production surplus as a function of the road development budget in Merauke Regency. This can be seen from the length of roads in Merauke district which has not increased but can increase yields of harvested commodities, and also from the construction of roads in Merauke regency.

\section{Conclusion}

The expected results in this study are to obtain a correlation and how much the road construction budget is with the production surplus, where if there is an increase in the road construction budget it can also increase the surplus in commodity production. With this correlation, it can be used as a model to become one of the decisions in determining development that can benefit the economic growth of people who are affected by the development of the transportation infrastructure.

\section{References}

1. Central Bureau of Statistics (2019) Merauke Regency in Figures 2019 (Merauke: Central Bureau of Statistics of Merauke Regency)

2. Anas R, Tamin O Z and Wibowo S S, Study of the Contribution of Road Infrastructure Invesment to the Regional Economy in Term of the Goods Transportation Sector 17th FSTPT Int. Symp, (2014).

3. Adisasmita R Basic Transportation Economics (Yogyakarta: Graha Ilmu Yogyakarta), (2010)

4. Saleh D Z, Mozaik of Indonesia's Infrastructure Problems ed M F Rahawarin and T M Cahyani (Depok: Ruas), (2014)

5. Risnawati, Widayati $\mathrm{W}$ and Magribi L O M The Infkuence of Road Infrastructure Development on Agricultural Development in Konawe Regency $J$. Perenc. Wil. IV 1-14, (2019)

6. Tamene S and Megento T L, Effect of rural transport infrastructure on the intensification of purchased input use for major food crop production: The case of smallholder farmers in Horro Guduru Wollega Zone, Western Ethiopia Acta Univ. Carolinae, Geogr. 54 168-81, (2019).

7. Prasetyo R B and Firdaus M, The Influence of Infrastructure on Regional Economic Growth in Indonesia J. Ekon. Dan Kebijak. Pembang. $2222-$ 36, (2009).

8. Maryaningsih N, Hermansyah $\mathrm{O}$ and Savitri M, The Influence of Infrastructure on Indonesia's Economis Growth Bul. Ekon. Monet. dan Perbank. 17 62-98, (2014). 